Discussion Paper No. 06-035

China's Exchange Rate Appreciation in the Light of the Earlier Japanese Experience

Ronald McKinnon

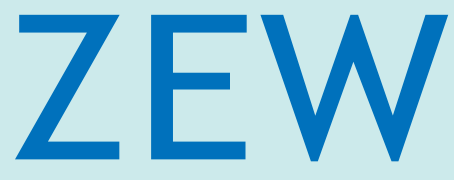

Zentrum für Europäische Wirtschaftsforschung $\mathrm{GmbH}$

Centre for European

Economic Research 
Discussion Paper No. 06-035

\title{
China's Exchange Rate Appreciation in the Light of the Earlier Japanese Experience
}

\author{
Ronald McKinnon
}

Download this ZEW Discussion Paper from our ftp server:

ftp://ftp.zew.de/pub/zew-docs/dp/dp06035.pdf

Die Discussion Papers dienen einer möglichst schnellen Verbreitung von neueren Forschungsarbeiten des ZEW. Die Beiträge liegen in alleiniger Verantwortung der Autoren und stellen nicht notwendigerweise die Meinung des ZEW dar.

Discussion Papers are intended to make results of ZEW research promptly available to other economists in order to encourage discussion and suggestions for revisions. The authors are solely responsible for the contents which do not necessarily represent the opinion of the ZEW. 


\section{Non-Technical Summary}

For creditor countries on the periphery of the dollar standard such as China that have current account (saving surpluses), foreign mercantile pressure to appreciate their currencies and become more flexible is misplaced. Just the expectation of (ongoing) exchange appreciation with high variance seriously disrupts the natural tendency for wage growth to balance productivity growth and thus worsens the (incipient) deflation that China now faces. It could create a zero-interest liquidity trap in financial markets that leaves the central bank helpless to combat future deflation arising out of actual currency appreciation as in the earlier experience of Japan (McKinnon and Ohno 1997). Exchange rate appreciation, or the threat of it, causes macroeconomic distress without having any predictable effect on the trade surpluses of creditor economies (Qiao 2005).

So what should China do? Absent foreign political pressure to appreciate, the first best economic solution would have been to keep the central parity rate of 8.28 yuan per dollar, as it was for the 10 years or so before July 21, 2005. If a fixed exchange rate is fully credible, both China's inflation and interest rates would converge to international levels. This would eliminate the threat of deflation and eliminate the possibility of a zero-interest liquidity trap with its attendant loss of monetary control. In the future, China may again have the opportunity at a politically propitious moment to fix its central exchange rate within a narrow band. The main idea is to reduce forward exchange rate uncertainty.

However, this first best economic solution may not now (February 2006) be politic. Since July 21, 2005, China's government appears to want the exchange rate to be more "flexible" and appreciate--perhaps because of foreign political pressure. Then, the second-best solution is to allow a slow gradual appreciation of the renminbi against the dollar but to embed the rate in continually rolled forward swap contracts between the People Bank of China and the commercial banks--as per the 2.9 percent solution described above. The uncertainty associated with future exchange rate movements is thereby reduced so that the negative risk premiums in both interest rates and wage growth are minimal. But China will then haveto live with mild price deflation relative to that in the United States and where interest rates on renminbi assets remain 2.9 percentage points or so less than those on dollar assets. In the future, however, if either U.S. interest rates come back down toward 3 percent or China speeds up renminbi appreciation, a zero-interest-rate trap will be difficult to avoid. 


\title{
China's Exchange Rate Appreciation in the Light of the Earlier Japanese Experience
}

\author{
Ronald McKinnon ${ }^{1}$ \\ Stanford University, USA
}

May 2006

\begin{abstract}
For creditor countries on the periphery of the dollar standard such as China with current account surpluses, foreign mercantile pressure to appreciate their currencies and become more flexible is misplaced. Just the expectation of variable exchange appreciation seriously disrupts the natural tendency for wage growth to balance productivity growth and thus worsens the (incipient) deflation that China now faces. It could create a zero-interest liquidity trap in financial markets that leaves the central bank helpless to combat future deflation arising out of actual currency appreciation, as with the earlier experience of Japan. Exchange rate appreciation, or the threat of it, causes macroeconomic distress without having any predictable effect on the trade surpluses of creditor economies.
\end{abstract}

Acknowledgement: The author would like to thank the ZEW for the invitation to Mannheim and all participants of the seminar of the department of Economics (University of Mannheim) for helpful comments and suggestions.

JEL-Classification: F31, F33, F42

Keywords: exchange rate, current account, China, Japan

1 Correspondence address: Department of Economics, Landau Economics Bldg., Stanford, CA 94305-6072, USA, Phone: 001650 723-3721, Fax: 001650 725-5702, Email: mckinnon@stanford.edu. 


\section{Introduction}

Today's American mercantile pressure on China to appreciate the renminbi against the dollar is eerily similar to the American pressure on Japan to appreciate the yen that began over 30 years ago. (See in the appendix my testimony before the U.S. Treasury on April 6, 2006 on whether or not China should be classified as a "currency manipulator".) Indeed, the yen went all the way from 360 to the dollar in August 1971, at the end of the Bretton Woods period of fixed exchange rate parities, to touch 80 to the dollar in April 1995. Then the American government relented and announced a strong dollar policy that signaled the end of "Japan bashing". But the overvalued yen, and the expectation of appreciation, destabilized the Japanese financial system; the bubble economy of the late 1980s was followed by a deflationary slump and a zero-interest liquidity trap in the 1990s [McKinnon and Ohno 1997].

At least some of today's critics of East Asian countries' pegging to the dollar would agree that international saving imbalances rather than misaligned exchange rates are the root cause of the U.S. current-account deficit. One can argue whether it is mainly a saving deficiency in the United States or a saving glut in the rest of the world [Bernanke 2005]. Either way, the central position of the United States under the world dollar standard gives it alone an unlimited international line of credit in its own currency.

However, suppose that the U.S. trade deficit is misdiagnosed to result from a misaligned exchange rate, so that a surplus country on the dollar's periphery is forced to appreciate against the world's dominant money. It will suffer a slowdown in economic growth including imports and eventually deflation [McKinnon 2005], with no predictable effect on its trade surplus [Qiao, 2005]—as with Japan from the 1970 s to the mid 1990s.

Since 2000, China bashing has not yet caused significant exchange appreciation despite a bill introduced into the U.S. Congress in March 2005 to impose a 27.5 percent tariff on all Chinese imports unless the renminbi is appreciated. However, after keeping the renminbi fixed at 8.28 yuan per dollar for more than 10 years during a period of very high growth and declining inflation, the People's Bank of China (PBC) announced on 21 July, 2005 that the rate would become more "flexible"-and allowed a 2.1 percent appreciation. Subsequent appreciation has been very small. The PBC has kept a tight rein on the spot exchange rate within a narrow trading range of \pm 0.3 percent. More important is the announcement effect, which increased the probability of future appreciations.

Indeed, on 25 November 2005, the PBC liberalized capital controls enough to create a swap market in forward exchange. With the spot rate at 8.08 yuan per dollar, it sold $\$ 6$ billion to a group of 10 domestic banks and promised to buy the dollars back 
one year hence at 7.85 yuan per dollar. This forward discount on the dollar of 2.9 percent implies that the PBC will tolerate gradual ongoing annual spot appreciations cumulating to a total of 2.9 percent in any one year. However, great uncertainty is involved: actual appreciation could be more or less, and it could be gradual or more discrete. American critics want much greater appreciation, closer to 20 to 35 percent [Bergsten et al 2005].

The upshot is that market participants now know that the renminbi will be higher against the dollar in the future: a one-way bet reinforced by China's growing trade surplus and foreign pressure. This expectation itself can influence China's economy even before substantial appreciation actually occurs. To show this, I first analyze the link between wage bargaining and productivity growth as they affect international competitiveness. Second, the implications for interest rates in China's not-yet-fully liberalized financial markets, where falling into a zero interest liquidity trap is quite possible, are explored. A useful benchmark is the earlier behavior of Japanese wages and interest rates in the face of a one-way bet on yen appreciation.

\section{Wage Adjustment under a Fixed Exchange Rate}

International saving imbalances aside, suppose a country such as China with low wages but very high productivity growth, trades with a country such as the U.S. with much lower productivity growth but higher real wages. When wages are "sticky" as traditional theory would have it, isn't exchange rate flexibility with ongoing appreciation of the renminbi more or less necessary to balance international competitiveness?

In the high-growth economy, however, wages are flexible. When wages grow about 10 percent per year, first differences are high relative to wage levels. International competitiveness can be roughly balanced in the short run when high quarterly wage increases match high productivity growth. In the very long run, the level of money wages in the high growth peripheral country converges to their level in the slower growing center. But the key is to ensure that monetary and exchange rate conditions are right so that high wage growth accurately reflects productivity gains.

In the 1950s and 1960s under the Bretton Woods system of fixed dollar exchange rates, how differential wage growth became the mode of international adjustment was first articulated for high-growth Scandinavia when the Swedish, Norwegian, and Danish currencies were all pegged to the dollar. But very high productivity growth in postwar Japan relative to the United States, when the yen/dollar rate was also convincingly fixed from 1949 to 1971, provided an equally striking example of what is now known as the Scandinavian Model (SM) of wage adjustment [Lindbeck, 1979]. When the high growth country's dollar exchange rate is credibly fixed, the SM has four key features: 
1) Relative purchasing power parity holds: inflation in tradable goods prices converges to that in the center country, in whose currency most world trade is invoiced.

2) Productivity growth in tradable (exportable) manufactures is higher than in the rest of the high-growth economy.

3) Employers in manufacturing, subject to the fixed exchange rate constraint, naturally bid up wages to fully reflect the higher productivity growth in manufacturing.

4) The high wage growth in manufactures then spreads out into the nontradables sector, where productivity growth is less, causing prices there to increase-the now classic Balassa-Samuelson effect.

When the yen was fixed at 360 to the dollar from 1950 to 1971 under Bretton Woods, the importance of relative wage adjustment between Japan and the United States was pronounced. In that period, Japan's annual growth in real output was 9.45 percent while industrial production grew an astonishing 14.6 percent-much like China's more recently. Unsurprisingly, the annual growth in Japan's labor productivity of 8.9 percent was far in excess of America's 2.6 percent. However, the balancing item was that average money wages grew at a robust rate of 10 percent per year in Japan and only 4.5 percent in the U.S. In Japan's manufacturing export sector with its extremely high growth in labor productivity, employers bid vigorously for both skilled and unskilled workers-subject to remaining internationally competitive at the fixed exchange rate. From 1950 to 1971, Figure 1 shows the dramatic rise of Japanese relative to American money wages.

Figure 1: Nominal Manufacturing Wage Growth for U.S. and Japan

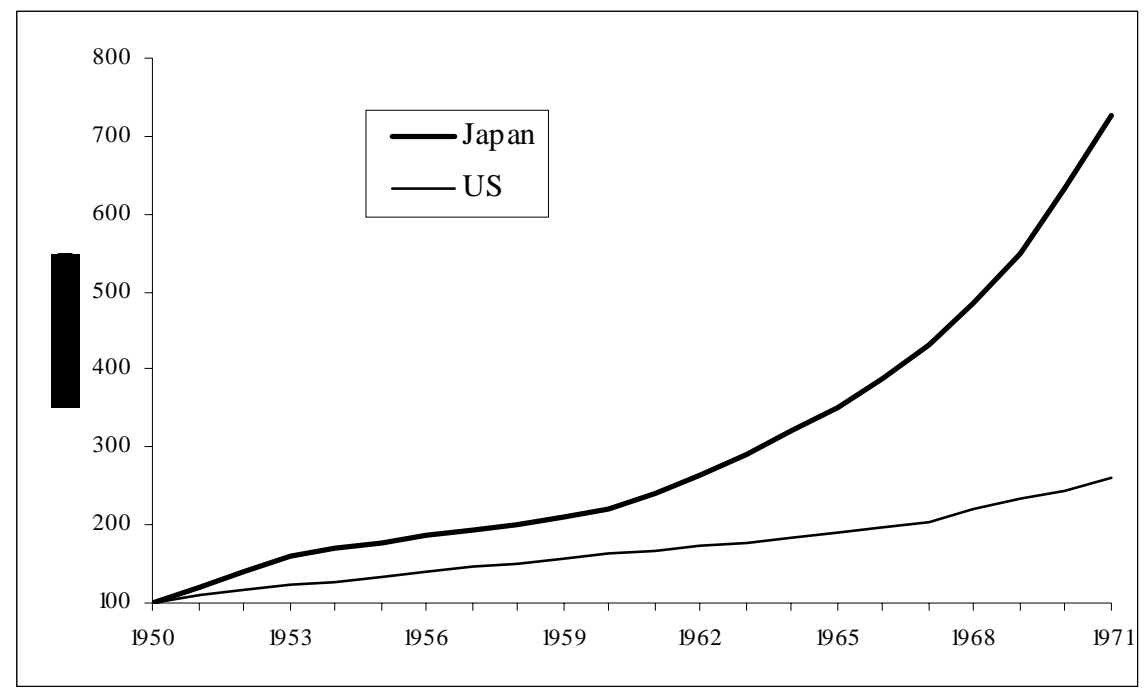


Figure 2: CPI Inflation and Wage Differential between Japan and U.S., and Yen/Dollar Rate, 1950-2004

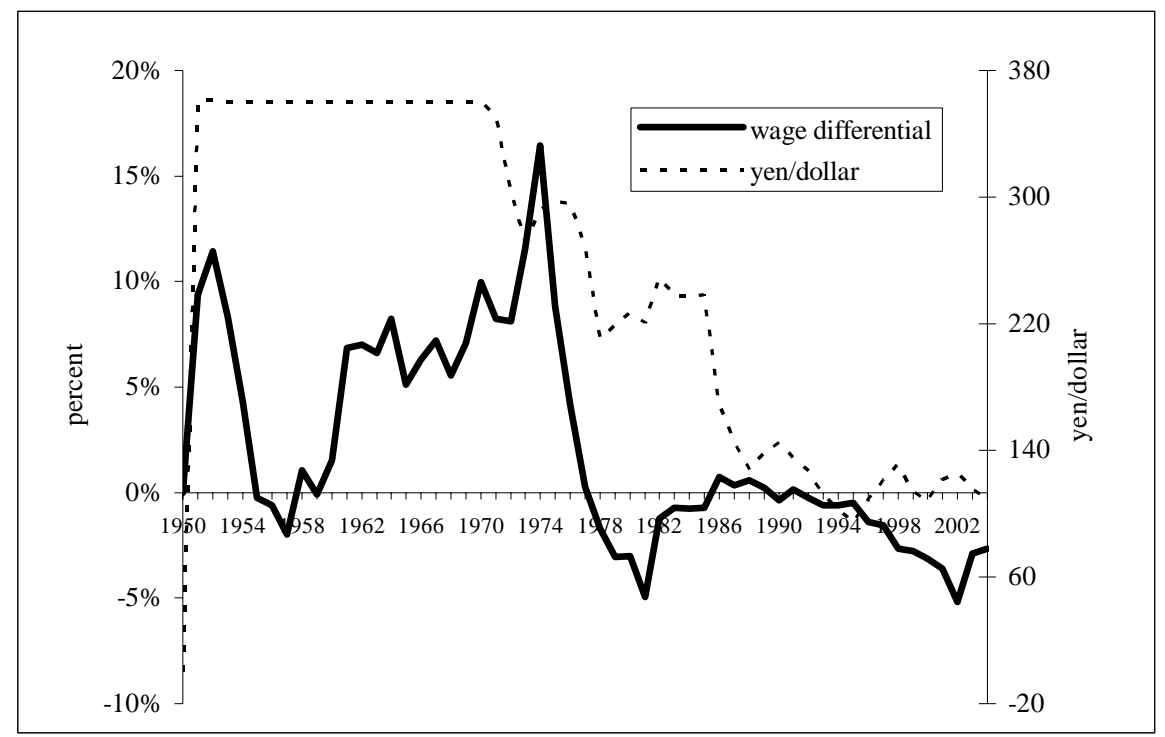

Source: G. Schnabl

Keeping the yen at 360 per dollar effectively anchored Japan's price level for tradable goods. In the 1950s and 1960s, the Japanese wholesale price index (WPI) rose less than 1 percent per year, whereas the American WPI rose a bit more than 1 percent. Because the bulk of world trade was invoiced in dollars, fixing an exchange rate to the dollar was (is) a stronger anchor for Japan's price level than the size of Japanese bilateral trade with the United States would have suggested. In addition, figure 2 shows the relatively high wage growth in Japan during the fixed rate period tailing off sharply to become less than that in the United States after the yen began to appreciate.

From 1994 to July 21, 2005, China had kept its exchange rate stable at 8.28 yuan/dollar. Figure 3 shows China's inflation (measured by its CPI) to be high in 1994-96, and, after 1998, to converge close to that in the United States: equilibrium in the sense of relative purchasing power parity. But how well did this fixed exchange rate policy anchor China's macro economy more generally? Coupled with the greater economic openness since the mid 1990s, it helped end the "roller coaster" ride in China's domestic inflation characteristic of the 1980s into early 1990s (Figure 4). But more was involved than just stabilizing inflation at a low level. Figure 4 shows that China's very high growth in real GDP also became more stable after 1996. No doubt other explanations of the end of China's roller coaster ride in both inflation and real growth rates are possible. However, the data are consistent with my hypothesis that fixing the nominal exchange rate provided a much needed nominal anchor when very rapid financial transformation made purely domestic monetary control mechanisms difficult to implement-as was also true of Japan in the 1950s and 1960s. 
Figure 3: China - US Inflation Differential and Exchange Rate, 1993-2005

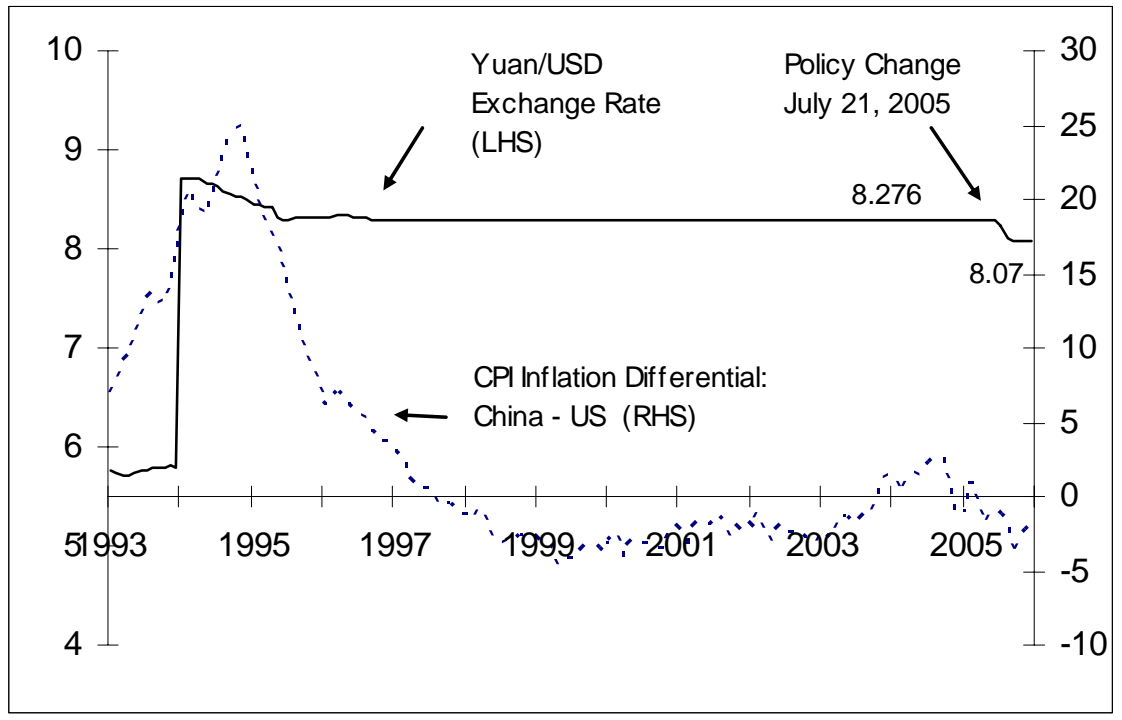

Figure 4: Inflation and Real Growth Rates of China, 1980-2005.

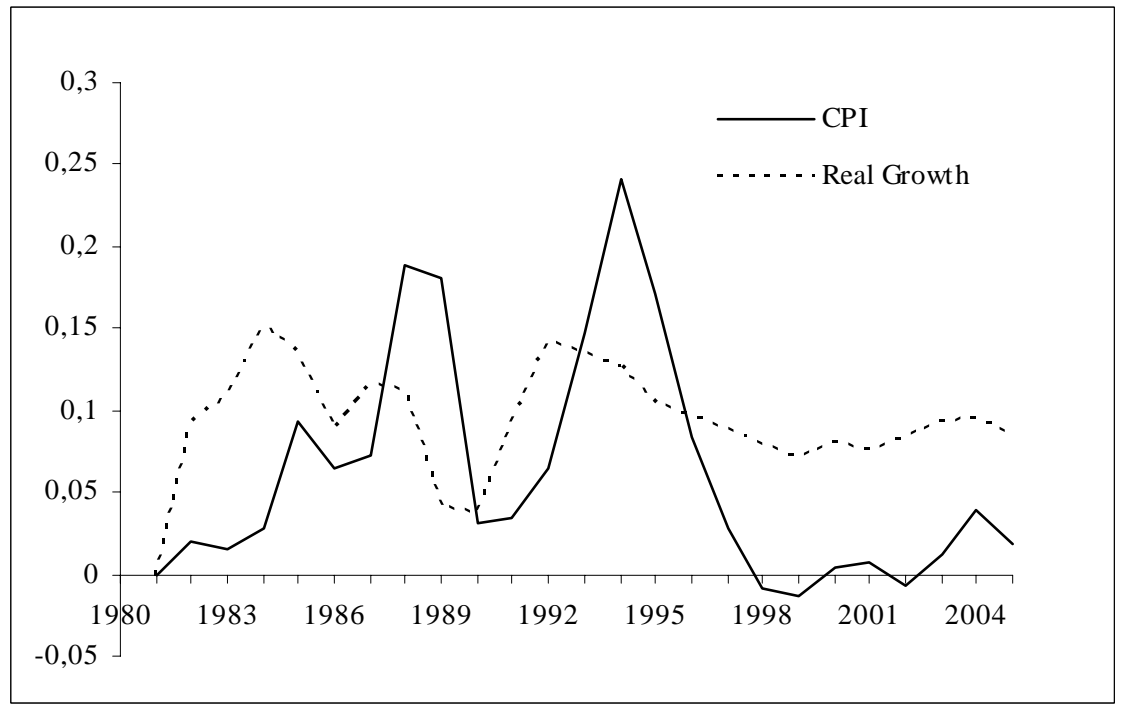

Source: G. Schnabl

But to preserve the exchange rate anchor, China's money wages had to grow in line with its rapid productivity growth. From 1994 through 2004, money wages in manufacturing increased 11.7 percent in China per year and by just 3.0 percent in the United States-see figure 5. This wage growth differential approximately reflected the differential growth of labor productivity: about 9.5 to 12 percent in China $^{2}$ versus 2.7 percent in the United States over the decade. Much of this extraordinary growth in Chinese wages reflects the upgrading of skills and greater work experience of the manufacturing labor force. True, at the margin, the wages of

2 Zhang and Tan (2004) estimated China's annual growth in labor productivity to be 12.32 percent from 1994 to 2001. Separately, using the World Bank's series on value added in domestic industrial production, productivity growth is estimated to be 9.41 percent from 1994 to 2004. 
unskilled migrant workers may be lagging - and many of these seem to be absorbed into construction activities where average wages show (slightly) slower growth. But, when the exchange rate was fixed, high wage growth in China seemed to balance international competitiveness - at least approximately given the highly imperfect data available—as the Scandinavian model would have it.

Figure 5: Nominal Manufacturing Wage Growth for U.S. and China, 1994-2004

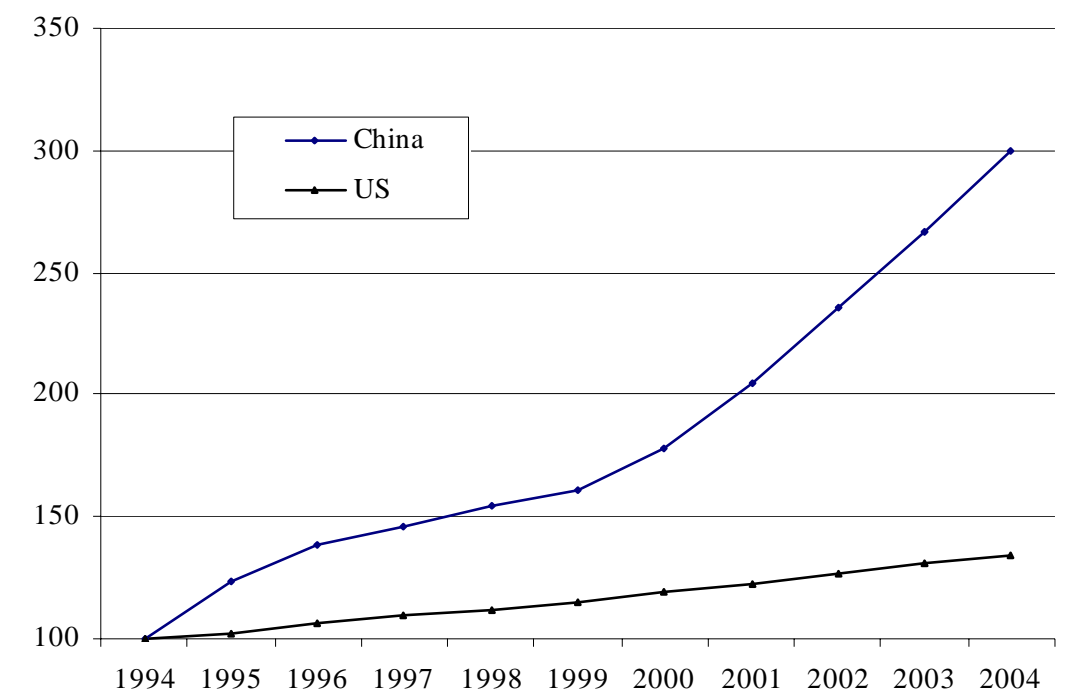

\section{The Negative Risk Premium in Wage Growth}

Suppose we modify our Scandinavian model of wage determination to introduce the expectation of renminbi appreciation, but the precise amount is uncertain. Because risk-averse employers in export activities don't know how much the renminbi will actually appreciate, they hesitate to bid money wages up by the full amount of productivity growth in tradables. A Chinese exporter could go bankrupt if he bid up incremental wages too strongly only to find that the renminbi appreciated more than his mean expectation. Let us call this shortfall in wage growth the negative risk premium in wage bargaining, $W R P<0$. Starting from a position where the domestic price level in China is stable (as was approximately true in 2005), wages increase according to

$$
\Delta W=E(\Delta P R O D)+E(\Delta S)+W R P
$$

where $W$ is money wages in China, $P R O D$ is (real) labor productivity, $S$ is yuan/dollar; $\Delta$ is the operator for percentage change, and $E$ is the expectations operator. $E(\triangle S)<0$ reflects expected appreciation, and $E(\triangle P R O D)>0$ reflects high productivity growth.

If the rate of appreciation was certain, say the renminbi was sure to appreciate by 2.9 percent per year, then $W R P=0$. Money wages would increase less than productivity 
growth by 2.9 percentage points. On a balanced deflation path, prices would fall 2.9 per year while real wages grew as much as labor productivity.

But the rate of renminbi appreciation in China is uncertain, so that $W R P<0$. It is still too soon (2005-2006) to get any firm estimate of the shortfall in wage increases in China from the uncertainty in exchange appreciation. However, the earlier Japanese experience of massive actual appreciations after 1970, which only later became more or less fully anticipated, provides a very rough comparison. Figure 2 shows the breakdown in relative wage adjustment-albeit with a lag. Before 1975, money wage growth in Japan remained much higher than in the United States. Subsequently, as relative deflation in Japan set in (particularly from the sharp rise in the yen in 1977-78), Japan's money wage growth slowed sharply. From 1980 to the present time, Japanese wage growth has been even lower than that in the United States. The erratically appreciating yen undermined the natural process of relative wage adjustment for balancing international competitiveness between Japan and the United States, and the resulting deflationary pressure severely depressed the Japanese economy in its "lost decade" of the 1990s.

\section{The Negative Risk Premium in Interest Rates}

Capital markets are known to be forward-looking, even more so than labor markets. So assuming that China continues with its liberalization of foreign exchange controls, and the People's Bank of China (PBC) eventually withdraws from pegging a variety of domestic deposit and loan interest rates, how will anticipated-but somewhat uncertain - exchange appreciation affect market-determined domestic interest rates?

Portfolio equilibrium between holding dollar and renminbi assets requires:

$$
i=i^{*}+E(\Delta S)+I R P
$$

where $i$ is the interest rate on a RMB asset, $i^{*}$ is the interest rate on a dollar asset of the same term to maturity, and IRP is the negative interest rate risk premium.

Under the world dollar standard, creditor countries like China or Japan don't lend much in their own currencies. Instead, their cumulative current account surpluses are largely financed by building up liquid dollar claims, privately or as official exchange reserves: the problem of "conflicted virtue" [McKinnon 2005]. Thus, if the yuan/dollar rate fluctuates, private holders of dollars in China see additional risk beyond the mean expectation of currency appreciation so that $I R P<0$. For portfolio equilibrium, the interest rate on renminbi assets must be less that on dollar assets by $|E(\Delta S)+I R P|$. 
Figure 6: Short-term Interest Rates: U.S., China and Japan, Jan, 2004 - Mar, 2006

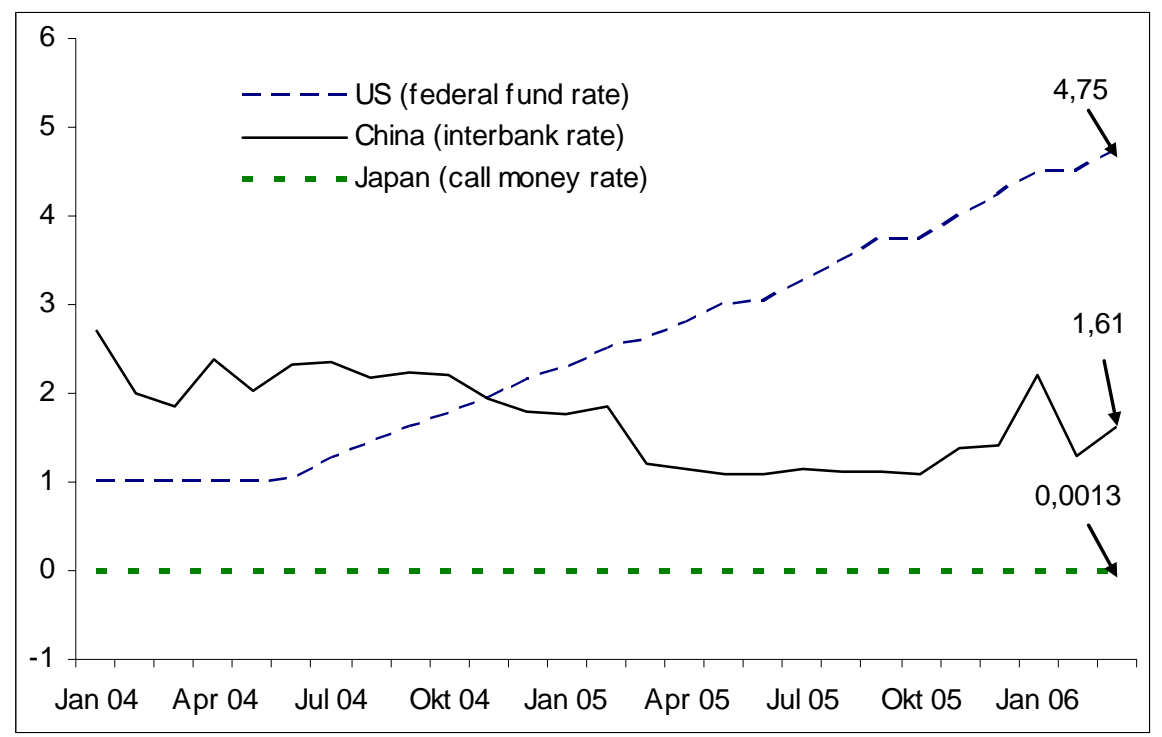

Financial liberalization is an important and laudable objective for improving the efficiency of China's capital markets in the long run. Now, however, with China's economy threatened by ongoing appreciation of the renminbi, liberalizing the financial system could have perverse short-run consequences. In the face of undiminished foreign exchange risk, i.e., the probability that the renminbi could appreciate, a near zero interest rate liquidity trap is possible. Figure 6 shows China's interbank interest rate at the end of 2005 falling toward 1.61 percent as the U.S. federal funds rate (coming off all time lows) rose to 4.75 percent. Although the PBC still pegs rates on bank deposits and some loans, China's interbank interest rate is fairly freely determined. (Figure 6 also shows Japan's short-term interest rate being stuck close zero: the dreaded liquidity trap.)

If interest rates on renminbi assets don't fall immediately to the level shown in equation (2), short-term capital (hot money) flows into China as investors try to switch their dollars into renminbi. To avoid an upward exchange rate spiral, the PBC must buy dollars in the foreign exchange market. The huge buildup of dollar exchange reserves, now well over US\$800 billion, and consequent internal expansion of the domestic monetary base, then drives down domestic short-term interest rates until they hit zero.

But another equilibrium, where Chinese interest rates remain low but above zero, is possible. This was suggested by the swap contract between the PBC and the commercial banks described above. If new swap contracts are initiated each month so that the forward discount on the dollar is always 2.9 percent (the rate of expected and actual annual appreciation of the RMB), then the PBC could secure domestic private portfolio equilibrium by keeping China's interest rate always 2.9 percentage points less than American. Coincidentally, 2.9 percent was about the actual interest differential at the end of 2005 (figure 6). If this smooth appreciation of 2.9 percent 
per year is certain, then the interest differential will be dominated by $E(\Delta S)$, and IRP $\rightarrow 0$.

However, if the exchange rate moves erratically and unpredictably, then the negative risk premium becomes more important. In Japan currently, the yen/dollar rate swings erratically but has shown no clear tendency to appreciate since 1995, after which Japan bashing pretty well ceased. In order to explain the large differential of more than 4 percentage points between Japanese and American interest rates as shown in Figure 6, the negative IRP must be very high in absolute terms even as $E(\Delta S) \rightarrow 0$. Japanese banks and insurance companies own huge stocks of dollar assets whose yen value fluctuates with the yen/dollar rate. To prevent massive dishoarding of these riskier dollar assets, the yield on yen assets must be much lower, i.e., $I R P<<0$. In the new millennium, this foreign exchange risk explains the current persistence of Japan's zero-interest liquidity trap even in the absence of any secular tendency for the yen to appreciate (McKinnon 2005, ch. 4).

\section{A Concluding Note}

For creditor countries on the periphery of the dollar standard such as China that have current account (saving surpluses), foreign mercantile pressure to appreciate their currencies and become more flexible is misplaced. Just the expectation of (ongoing) exchange appreciation with high variance seriously disrupts the natural tendency for wage growth to balance productivity growth and thus worsens the (incipient) deflation that China now faces. It could create a zero-interest liquidity trap in financial markets that leaves the central bank helpless to combat future deflation arising out of actual currency appreciation as in the earlier experience of Japan (McKinnon and Ohno 1997). Exchange rate appreciation, or the threat of it, causes macroeconomic distress without having any predictable effect on the trade surpluses of creditor economies (Qiao 2005).

So what should China do? Absent foreign political pressure to appreciate, the first best economic solution would have been to keep the central parity rate of 8.28 yuan per dollar, as it was for the 10 years or so before July 21, 2005. If a fixed exchange rate is fully credible, both China's inflation and interest rates would converge to international levels. This would eliminate the threat of deflation and eliminate the possibility of a zero-interest liquidity trap with its attendant loss of monetary control. In the future, China may again have the opportunity at a politically propitious moment to fix its central exchange rate within a narrow band. The main idea is to reduce forward exchange rate uncertainty.

However, this first best economic solution may not now (February 2006) be politic. Since July 21, 2005, China's government appears to want the exchange rate to be more "flexible" and appreciate--perhaps because of foreign political pressure. Then, 
the second-best solution is to allow a slow gradual appreciation of the renminbi against the dollar but to embed the rate in continually rolled forward swap contracts between the People Bank of China and the commercial banks--as per the 2.9 percent solution described above. The uncertainty associated with future exchange rate movements is thereby reduced so that the negative risk premiums in both interest rates and wage growth are minimal. But China will then have to live with mild price deflation relative to that in the United States and where interest rates on renminbi assets remain 2.9 percentage points or so less than those on dollar assets. In the future, however, if either U.S. interest rates come back down toward 3 percent or China speeds up renminbi appreciation, a zero-interest-rate trap will be difficult to avoid. 


\section{References}

Bergsten, C. Fred et al. The United States and the World Economy, Institute for International Economics, Washington DC 2005.

Bernanke, Ben. The Global Saving Glut and the U.S. Current Account Deficit, At the Sandridge Lecture, Virginia Economics Association, Richmond, 10 March 2005.

Lindbeck, Assar. Inflation and Unemployment in Open Economies, Amsterdam, North Holland, 1979..

McKinnon, Ronald, and Kenichi Ohno. Dollar and Yen: Resolving Economic Conflict between the United States and Japan MIT Press, 1997 (Translations: Japanese 1998, Chinese 1999).

McKinnon, Ronald. Exchange Rates under the East Asian Dollar Standard: Living with Conflicted Virtue MIT Press, 2005. (Chinese translation, 2005; Japanese forthcoming, 2007).

Qiao, Hong. "Exchange Rates and Trade Balances under the Dollar Standard". Stanford University, Center for International Development, China Working Paper Series, August 2005.

Zhang, Xiaobo, and Kong-Yam Tan, "Blunt to Sharpened Razor: Incremental Reform and Distortions in the Product and Capital Markets in China”, International Food Policy Research Institute, DSGD Discussion Paper \#13, August 2004. 


\section{APPENDIX}

\section{Attn: Request for Public Comments on the Report to Congress on International and Exchange Rate Policies. (presented at U.S. Treasury on 6 April 2006)}

\section{Comment: Professor Ronald I McKinnon, Stanford University}

Section 3004 of Public Law 100-418 requires that the U.S. Secretary of the Treasury assess whether countries such as China that have global current account surpluses or large bilateral trade surpluses with the United States are manipulating their exchange rates to prevent effective balance of payments adjustment or to gain an unfair competitive advantage in international trade. The law as written presumes that current account surpluses are evidence of currency manipulation by the foreign countries in question. But as shown below, China's motivation for pegging its exchange has been to secure internal monetary stability and not to achieve an undue mercantile advantage in world export markets.

From 2000 to 2004, China has had the world's largest bilateral trade surplus with the United States. But since then, the collective trade surpluses of the oil exporting countries have become larger than China's surplus. The key difference, however, is that China is a major exporter of manufactured goods that sometimes compete with U.S. manufactures, whereas imports of oil and natural gas are viewed as vital inputs for American industry. This difference explains the current concern in the Congress with possible "unfair" competition from China but not from oil exporters despite their proportionately larger surpluses. Still, China's current bilateral trade surplus with the United States is about one-quarter of America's huge and growing trade deficit, about 7 percent of U.S. GDP so far in 2006.

Section 3004 fails to recognize that persistent trade surpluses in China and trade deficits in the United States are not evidence of a misaligned or manipulated yuan/dollar exchange rate. Instead, they reflect very high saving in China and unusually low saving the United States. China's saving is even higher than its own extraordinarily high domestic investment of about 40 percent of GDP, whereas saving in the United States is very low relative to a more normal level of domestic investment of about 16 to 17 percent of GDP. The result is that China (like many other countries in Asia) naturally runs an overall current account surplus while the U.S. runs a current account deficit.

America's large current account deficit-more in goods than in services-reflects borrowing from the rest of the world to cover its saving deficiency. Without this saving transfer allowing the U.S. to spend more on goods and services than it produces, the U.S. would suffer a credit crunch. Interest rates would increase so that investment-both industrial and residential-would fall. If this cessation of net foreign lending to the U.S. happened suddenly causing the current account deficit to 
fall quickly, and if there was no correction in America's saving deficiency, the U.S. economy would be forced into a sharp cyclical downturn similar to the "credit crunch" of 1991-92. On the other hand, if the reduction in net foreign lending was gradual and spread over many years, the cost would be that America's longer term economic growth would slow as domestic investment and the current account deficit fell in tandem as a proportion of GDP.. *

So there are two main points to recognize. First, an exchange rate change cannot correct America's current account and saving-investment imbalance. Second, if the saving rate in the United States were to increase gradually through time, then its current account deficit would gradually diminish—but still without requiring any substantial change in nominal dollar exchange rates with major trading partners including China.

Increased U.S. saving must come from two sources: the federal government and the household sector. (U.S. corporate saving from retained profits remains robust.) Strenuous efforts must be made reduce the U.S. federal fiscal deficit, which is a terrific drain on national saving of 3 to 4 percent of GDP. Tax revenues have fallen to an unduly low level by international standards. Dealing with deficient, perhaps negative net, household saving is conceptually a much trickier problem. But some program of "forced" saving, from a national pension plan above and beyond social security contributions, should be considered. Singapore's Provident Fund could be a good model.

However, suppose the U.S. current account deficit is misdiagnosed as an exchange rate problem. More than 20 years ago, when Japan had the largest bilateral trade surplus with the United States, the U.S. exerted continual pressure on Japan to appreciate the yen. Indeed, the yen went all the way from 360 to the dollar in 1971 to peak out at just 80 to the dollar in April 1995. This induced a bubble in Japanese stock and land prices in the late 1980s that collapsed in 1991. A deflationary slump and a zero interest liquidity trap followed in Japan's "lost decade" of the 1990s. But the higher yen led to no obvious reduction in Japan's trade surplus as a share of its slumping GDP.

Could the same thing happen to China? From 1994 through early 2005, China fixed its exchange rate at 8.28 yuan per dollar by focusing its national monetary policy on maintaining that rate. The idea was to use the dollar exchange rate to anchor China's price level at a time when great financial transformation made domestic monetary indicators difficult to interpret. And this policy was successful in ironing out the previous "roller coaster ride" in domestic price inflation and growth rates. China's high inflation of the mid 1990s came down and converged to that in the United States_-as the principle of relative purchasing power parity would suggest. 
Now China has come under great pressure-mainly from the United States-to appreciate the renminbi. Since July 21, 2005 the renminbi has appreciated slowlyonly about 3.5 percent so far. But Section 3004 is an important part of continuing American political pressure on China for further appreciation. In early 2006, China's year-over-year CPI inflation has fallen to just 1 percent, whereas America's is over 3 percent. Clearly, any substantial further appreciation will push China into a situation where its CPI begins to fall. To be sure, China's real economy still remains robust. But one cannot rule out the possibility of a Japanese-style deflationary slump if China's is continually forced to appreciate the renminbi because bad economic theory suggests that a higher renminbi will eventually reduce its trade surplus. 